Suzanna Windon

\title{
SUPPORT FOR ORGANIZATIONAL CHANGE AMONG EXTENSION EDUCATORS
}

\begin{abstract}
This study sought to assess perceptions of support for organizational change and model the relationship between support for organizational change and leadership competencies among Extension educators. The knowledge gained through this work should expand current understandings regarding the nature, scope, and value of support for organizational change within the Extension educator role. We found that Extension educators mostly support organizational change. Our study also showed that leadership competencies predict a significant proportion of the total variation in overall support for organizational change. Extension leaders and leadership development practitioners should be aware that leadership education may increase receptivity to organizational change among educators.
\end{abstract}

\section{Introduction}

Organizational change can be disconcerting. Employees tend to dislike change because it brings uncertainty and fear (Kinsey 2010). The term organizational change refers to changes an organization implements to improve efficiency (Smith \& Torppa, 2010; Struckmeyer et al., 2019). The term organizational readiness for change refers to an organization's employees' commitment to and confidence in implementing organizational change (Weiner, 2020). Smith and Torppa (2010) indicated that "in a climate of continuous change, Extension organizations must find ways to navigate immediate challenges while developing the capacity to thrive as future challenges and opportunities arise," p.1. The continuous change affects personnel fatigue and makes them cynical about the outcomes of organizational change attempts (Smith \& Torppa,
2010). Extension organizations are facing global pandemic challenges, technological innovations, and the shift to a knowledge-based workforce. These factors change how Extension educators operate programs (Smith \& Torppa, 2010; Struckmeyer et al., 2019). Extension organizations should be committed to becoming a "learning organizations" that may help flourish continuous change. Knowing that organizational change can increase fear, this study's findings may help answer the question: What can Extension leaders and leadership development practitioners do to prepare their personnel to support organizational change?

Leadership Education for Extension Educators. Extension's core mission is improving quality of life through education (Pettigrew, Ferlie, \& McKee, 1992). An Extension educator is a university Extension employee who develops, delivers, and evaluates 
educational programs in the specific program areas to help improve life in rural and urban areas. Currently, Penn State Extension educators' only required leadership training is their onboarding training at the onsite of employment, which includes a two-day workshop to introduce them to Penn State Extension and provide training on leadership development techniques. In concert, various webinars are offered by the professional development committee that educators can elect to participate in or not participate in. Each year educators are offered a variety of professional development opportunities at the Penn State Extension Annual Conference as well. Some are delivered as keynote speakers for all participants while others are offered as optional sessions. All sessions are recorded for viewing after the conference as another option for professional development at a later time (Pusey, R., personal communication, December 2020). However, we want to hypothesize that enhancing educators' leadership competencies positively affect their receptivity to organizational change. Understanding Extension educators' orientation toward organizational change is critical as Extension works to adapt to the $21^{\text {st }}$ century (Bloir \& Scheer, 2017) because new opportunities and challenges are presenting themselves in Extension work (Smith \& Torppa, 2010). Identifying leadership competencies of Extension professionals is also an area of interest for the modern Extension organization (Hyde, J, \& Cason, K., personal communication, October 2018). To address both of these needs of the modern Extension professional, we conducted a quantitative study among Penn State Extension educators to determine if educators' leadership competencies predict support for organizational change.

The purpose of this study is to enhance our understanding of supportive/positive employee reaction to organizational change in the context of intrapersonal and interpersonal leadership skills. This research addresses a question that is essential for Extension organizations pursing strategic change and how employees' intrapersonal and interpersonal leadership skills can predict their resistance to organization change. Past research has placed considerable emphasis on various factors that can minimize employee resistance to change. Consequently, this article tries to link observed differences in the levels of support for change among employees to several leadership factors, in addition to existing leadership practices. In this article, we will continue build the knowledge in the areas of leadership and organizational change literatures. This exploratory study is the first work that investigates the relationship between employees' leadership competencies and their support for organizational change.

The knowledge gained through this work should expand current understandings regarding the nature, scope, and value of support for change within the Extension educator role and their leadership competencies. This article addresses a gap in the literature and discusses the relationship between Extension educators' perceptions of support for organizational change and Extension educators' leadership competencies. Findings are presented to help guide Extension scholars and practitioners in future assessments and research related to leadership and support for change among Extension professionals. In the discussion and implications, we relate our findings to past literature and identify future directions of study. In addition, we discuss the implications for practitioners of Extension leadership professional development materials.

\section{Literature Review}

Employees Support for Organizational Change. In 2009, Helms Mills et al. defined organizational change as an alteration of a core aspect of an organization's 
operation. Implementation of organizational change is a challenge because its inherent risk (Stebbings \& Braganza, 2009). Approximately 70 percent of organizational change initiatives fail to achieve their intended results (Beer \& Nohria, 2000; Nikolaou et al., 2007). One of the challenges for leaders is implementing planned organizational changes towards more effective outcomes (Battilana et al., 2010). The leadership theories and models emphasize the importance of envisioning and leading change for organizational development (Zaccaro \& Banks, 2004). The authors wrote:

Followers can often be intimidated or anxious about change, specifically about whether they can perform as well under new conditions. The leader's task becomes that of convincing subordinates of their capability to handle change indeed, to embrace it and be optimistic about their future performance (p.371).

Over the last three decades, research about transformational and charismatic leadership has investigated the relationship between leadership competencies, behaviors, skills, characteristics, and organizational change (Bass, 1985, 1996, 1999; House \& Aditya,1997; Yukl, 1999, 2006). Bass's model of transformational leadership (Bass, 1985, 1996) indicates that the organization leader should motivate employees to perform beyond expectations and be committed to the organization and its mission. Murray and Blackman (2006) wrote:

. . . organization members possess the resolve to challenge old values and/or are opposed to the existing ones. Moreover, organizational members seldom possess the power and ability to express their opposition to the status quo, since individuals become prisoners of the system sand rules that stultify and oppress learning." p.134.
The authors also indicated that organization innovations for change requires creating an effective learning culture. McRoy and Gibbs (2009) wrote that training aimed at securing organizational change depends heavily on effective leadership. The authors emphasized that leadership education plays an essential role in the organizational change management process because it helps communicate strategic vision, lead effective implementation, and possess the leadership competencies to deal with barriers and fears associated with the change process. The authors also indicated that managing the process of change is an essential skill both at a personal and professional level. In 1996, Kotter discussed the eight-stage process for leading change that has become highly recognized for its step-bystep guidance for leading organizational change (Appelbaum et al., 2012; Hughes, 2016, Kaufman et al., 2020). Years later, Kotter (2014) revised his approach with accelerators for a change instead of stages. One of this framework's critical points is the alignment with motivation theory and improvement science in education that support collaboration between educators and the audience and audience achievements (Kaufman et al., 2020).

\section{Intrapersonal and Interpersonal Leadership} Competencies. Day and Dragoni(2015) differentiated two dimensions of a leaders' development over time: the intrapersonal dimension and the interpersonal dimension. Intrapersonal leadership development includes human capital development that includes an individual-based knowledge, skills, and abilities (Day, 2000). Specific examples of the intrapersonal leaders' competencies are self-awareness, self-motivation, and self-regulation (McCauley, 2000; Day \& Dragoni, 2015). Intrapersonal leadership competencies also reflect the role of responsibility, work, and careergrowth orientation (Boyce et al., 2010; Mumford et al., 2000). On the other hand, social capital development in an organization reflects the capacity for leaders and employees to engage with others through the building of network relationships and interpersonal exchange (Avolio \& Gardner, 2005; Bourdieu, 1986; 
Day, 2000; Galli \& Müller-Stewens, 2012; Subramony et al., 2018). Specific examples of the intrapersonal leaders' competencies are commitment, trust and trustworthiness, social awareness and communication skills, and shared vision (Coleman, 1988; Day 2000; Bouty, 2000; Tsai \& Ghoshal, 1998; Subramony et al., 2018). Interpersonal leadership competencies refer to the ability to understand other people (Gardner, 1993).

Despite the lack of research on interpersonal skills in developing leaders, there were studies in the 1900s demonstrating that communication and social skills were significant predictors of leadership effectiveness (Bass, 1990; Riggio \& Lee, 2007). Likert (1961) provided a theoretical foundation for interpersonal skills training based on a distinction between task-oriented leader behaviors and relationship-oriented behaviors. In 1953, Fleishman promoted to enhancing the relationship-oriented aspects of leader behavior that led to programs aimed at developing the interpersonal relationship skills of leaders. More recent Leader-Member Exchange leadership theory also recognizes the importance of interpersonal skill training in effective leadership because it emphasizes the quality of leader-follower relationships (LMX; Uhl-Bien, 2003). Riggio and Lee (2007) recommended developing leadership development programs that specifically focus on enhancing interpersonal skills. The authors also suggested measuring the effectiveness of such training efforts because it helps understand the domains of interpersonal skills, which have not been specifically applied to leadership in the past.

\section{Relationship between Support for Change and} Leadership Competencies. Battilana et al. (2010) wrote that a variety of leadership competencies and activities from employees can help to facilitate planned organizational change. The authors found that leadership skills, including goal-setting and followthrough, accountability, active listening, rapportbuilding, trust, and vulnerability positively affect the mobilization, evaluation, and communication activities associated with planned organizational change implementation. In 2019, Struckmeyer et al. conducted a study to determine factors that affect support for a new caregiving method among family and consumer sciences Extension educators. The authors found that educators with leadership selfefficacy predicted support for change. Support for change was also significantly predicted by current position, interoffice support, and social support.

Leadership Competencies within Extension. The development of leadership competencies has been an area of scholarly inquiry of county Extension educators (Argabright et. al., 2019; Benge et al., 2011; Boyd, 2004; Benge \& Sowcik, 2018; Bruce \& Anderson, 2012; Ladewig \& Rohs, 2000; Haynes, 2000; Lakai et al., 2014, Ricketts et al., 2010; Woodrum \& Safrit, 2003; Stedman \& Rudd, 2006) and state specialists (Radhakrishna, 2001). Leadership competencies have also been identified to guide undergraduate academic plans for future Extension professionals (Scheer et al., 2006). Argabright (2019) and colleagues conducted a review of literature of several resources on Extension competencies. They found that management, communication, diversity, interpersonal leadership skills, and networking were critical leadership skills for the modern Extension professional. Benge and Sowcik (2018) examined leadership skills needed for Extension professionals. The authors identified roles of a leader, leader identity, building strong relationships with others, creating an extraordinary leadership environment, leadership best practices, and developing a leadership development plan as leadership competencies needed for county Extension directors. Benge et al. (2011) asked Florida Extension agents what pre-entry competencies they believed were needed for Extension work. Out of the most important professional competencies identified, leadership competencies included: selfmanagement and communication skills. Other assessed leadership skills were problem-solving, professionalism, leadership development, ability to foster volunteer development, and teamwork skills. Haynes (2000) assessed Extension county directors' 
management skills. He found the following leadership skills are needed for county Extension work: oral communication, organization skills, leadership, decision-making, ability to take initiative, ability to mentor coworkers, perception and sensitivity, collaboration, written communication, flexibility, organizational awareness, and assertiveness. Franz et al. (2002) found that extension educators' engagement in dialogue with the community skills are critical for organizational change.

\section{Organizational Change within Extension.} Extension leaders must successfully navigate immediate and continuous changes in the organizational environment. Creating an atmosphere for continuous personal development can stimulate employees' capacity to thrive through current and future challenges (Smith \& Torppa, 2010). Studies that were conducted in 1990s suggested that organizational leaders should manage and guide change (Graetz, 2000; Limerick \& Cunnington, 1993). More recent studies indicated that organization leaders must know how to create change to address unpredictable situations. (Clampitt \& Williams, 2005). Despite the plethora of studies examining leadership development for Extension educators, few studies in the literature were identified related to Extension professionals' level of support for organizational change. In concert, none of the identified studies examined the relationship between Extension professionals' leadership competencies and support for change. Bloir and Scheer (2017) conducted a study among Ohio State University Extension professionals, assessing their receptiveness for change. The scholars found neutral levels for resistance to change ( $M=3.1,6$-point Likert scale) and relatively high levels for change readiness ( $M=5.4$, 7-point Likert scale). Extension is being forced to cope with fundamental changes that affect the balance of its organizational structure. Reorganization creates pressures on Extension employees (Tondl, 1991). Smith and Torppa (2010) examined attitudes related to change within the Extension organization. They found that employees involved in all steps of the change process were more likely to be open to change. The results also indicated more involved individuals were more likely to be motivated to help implement the change successfully. However, the authors cautioned that excessive employee participation in the change process could create fatigue, apathy, and resistance. The knowledge of employee reaction to organizational change is vital to the planning and implementation of strategies by the organization (Battilana et al., 2010; Zaccaro \& Banks, 2004; Vithessonthi \& Schwaninger, 2008). This raises important questions. What factors affect whether employees support organizational change?

\section{Purpose and Research Objectives}

This quantitative study seeks to assess perceptions of two dimensions of support for change among Penn State Extension educators, as well as model the relationship between support for change and intrapersonal and interpersonal leadership competencies among Extension educators. The knowledge gained through this work should expand current understandings regarding the nature, scope, and value of support for change within the Extension educator role. The current study was guided by four research objectives:

1. Describe Extension educators' perceptions of their intrapersonal leadership competencies.

2. Describe Extension educators' perceptions of their interpersonal leadership competencies.

3. Describe Extension educators' perceptions of their support for organizational change.

4. Explain the relationship between Extension educators' perceptions of support for change and perceived intrapersonal and interpersonal leadership competencies. 
The study reported here is an offshoot of a more comprehensive study that we conducted in 2019. In the comprehensive study, we examined extension educators' job motivation, support for change, and demographics characteristics. The leadership competencies factor was identified as a factor that affected support for organizational change. In the research reported here, we investigated intrapersonal and interpersonal leadership competencies that influence employees' support for organizational change.

\section{Methods}

The present study of support for change was completed using a survey research method. An online survey was utilized to collect data from the Penn State Extension educators, administered via Qualtrics.

Participants and Data Collection. The target population for our study was Penn State Extension educators. In our study, we used a census approach and followed Dillman's et al., (2014) online data collection technique. The acting director of Penn State Extension sent a pre-notification email to Extension educators and ask them to participate in this study. We sent a second pre-notification email and four email reminders. Data collection occurred in spring 2019. The population of the study reported here was 149 Penn State Extension educators with full-time employment appointments. After removing responses with missing data, the final data set included responses from 111 employees, providing a response rate of $74.5 \%$. Most participants were women (66.7\%). Approximately $32 \%$ of participants had worked at the Extension for less than five years. Almost $40 \%$ of participants had more than 15 years of tenure within organization.
Instrumentation, Validity and Reliability. We used a survey method to address the four research objectives of this study. We used an online questionnaire administered via Qualtrics to explore Extension educators' perceptions of intrapersonal and interpersonal competencies and support for organization change. We developed the Intrapersonal Leadership Scale and Interpersonal Leadership Scale using existing literature related to the leadership, specifically intrapersonal and interpersonal leadership competencies (Benge et al., 2011; Bruce \& Anderson, 2012; Conklin et al., 2002; Cooper \& Graham, 2001; Day, 2000; Day and Dragoni, 2015; Goleman, 2004; Haynes, 2000; MPI, 2012; Paxson et al., 1993; Stedman \& Rudd, 2006; Sage, n.d.; Subramony et al., 2018; Ulvenblad et al., 2014). We adapted Vithessonthi and Schwaninger's (2008) three-item, Support for Change Scale. This scale measured the degree of behaviors that represented employees' support for change. Both scales' items were measured using a five-point Likert scale ranging from 1 (strongly disagree) to 5 (strongly agree). The reliability of the original scale was 0.70 .

A panel of five Extension educators, Extension administrators, academic faculty members with expertise in survey methodology, and a graduate student in Extension education reviewed the instrument for face and content validity. The panel of experts determined that the instrument is sufficiently valid. To determine reliability of the created instrument, a pilot test was conducted. We used the Dillman, et.al., (2014) method for online data collection for our pilot test. For the pilot study, we selected 35 Penn State Extension educators. The response rate for individuals completing the pilot study was $68 \%(n=24)$. The reliability coefficient of the Intrapersonal Leadership Scale in this study was .839. We asked respondents to indicate how strongly they agreed with the intrapersonal leadership area using a Likert-type scale, where 1 = strongly disagree, 2 = disagree, 3 = neither disagree nor agree, 4 = agree, 5 = strongly agree. Examples of the items: "I have a clear set of values that I apply in the workplace", "I easily prioritize tasks when I am involved in various 
projects." The reliability coefficient of the Interpersonal Leadership Scale in this study was .916. We asked respondents to indicate how strongly they agreed with the interpersonal leadership area using Likerttype scale, where 1 = strongly disagree, 2 = disagree, 3 = neither disagree or agree, 4 = agree, 5 = strongly agree. Examples of the items: "I form external partnerships in the community to enhance my work," "I am comfortable working with diverse audiences." The third scale asked respondents to indicate how strongly they agreed with support for organization change using a Likert-type scale, where 1 = strongly disagree, 2 = disagree, 3 = neither disagree or agree, 4 = agree, 5 = strongly agree. The reliability coefficient of the overall Support for Organizational Change Scale in this study was .829. Examples of the items: "I certainly comply with organizational change", "I agree with organizational change."

Control for Non-response Error. Early and late responses were compared to evaluate non-response error in this study (Miller \& Smith, 1983). The first forty respondents were assigned as an early phase respondent group and the last forty respondents were identified as a late phase respondent group. The early and late phases of responders were determined based on the day and time their questionnaire was submitted. We conducted an independent $t$-test to determine if group mean for total scores on the four measured constructs differed between the two groups of respondents (early and late). The results of the independent samples $t$-test (alpha level of .05 , two tailed) for equality of means for scale scores of constructs between early and late showed there were not statistically significant differences between early and late respondents. The results of $t$-test suggesting non-response bias was not an issue (Lindner et al., 2001; Miller \& Smith, 1983) and it reveals that that data collected from Extension educators were representative of the entire study population (Table 2.)

Caution is advised in interpreting the study findings since the participants of the study are not a random sample. The findings of this study will only apply to those who participated, and as such cannot be generalized to the entire population of Penn State Extension educators.

\section{Table 2}

Independent Samples t-test for Equality of Means on Scale Scores of Construct between Early and Late Respondents.

\begin{tabular}{|l|l|l|l|l|l|l|l|}
\hline Scale & \multicolumn{3}{l|}{ Respondents } \\
\cline { 2 - 10 } & Early $(n=40)$ & \multicolumn{2}{l|}{$\begin{array}{l}\text { Late }(n= \\
40)\end{array}$} \\
\hline & $M$ & $S D$ & $M$ & $S D$ & $t$ & $p$ \\
\hline Intrapersonal leadership skills & 4.15 & .36 & 4.03 & .34 & 1.493 & .139 \\
\hline Interpersonal leadership skills & 4.10 & .43 & 3.98 & .47 & 1.088 & .280 \\
\hline Support for organizational change & 3.39 & .60 & 3.99 & .56 & -.323 & .748 \\
\hline
\end{tabular}

Data Analysis. We used SPSS $®$ version 24 to conduct data analysis for our study. Independent variables and the dependent variable, support for change, were treated as interval data. A descriptive statistic was utilized to describe the first three research objectives. For research objective four, we used an application of the Pearson correlation coefficient to measure associations between overall intrapersonal, interpersonal leadership skills, and support for change. A multiple linear regression analysis was conducted to answer the last research question determine the relationship between overall support for change (dependent variable) and independent variables, such as intrapersonal leadership skills 
and intrapersonal leadership skills. Also, we used standard Davis Conventions (1971) to describe the magnitude of the correlation between independent and dependent variables, (see Table 3).

\section{Table 3}

Describing the Magnitude of Correlations Based on Davis' (1971) Conventions

\begin{tabular}{ll|}
\hline Magnitude of correlation coefficient & Description \\
\hline 1.00 & Perfect association \\
0.70 or higher & Very strong association \\
0.50 to 0.69 & Substantial association \\
0.30 to 0.49 & Moderate association \\
0.10 to 0.29 & Low association \\
.01 to 0.09 & Negligible association \\
\hline
\end{tabular}

Note. Adapted from Davis. J.A. (1971) "Elementary survey analysis" Englewood, NJ: Prentice-Hall.

\section{Findings}

The first research objective was to describe Extension educators' perceptions of their intrapersonal leadership competencies. The mean summative score for intrapersonal leadership skills was 4.12 (SD $=.378, n=111$ ). Results for this objective are shown in Table 4. Lower scores indicate greater needs of intrapersonal leadership skills content areas, and higher scores indicate greater proficiency in the area. The survey items scoring the highest mean values were (a) I have a clear set of values that I apply in the workplace. $(M=4.80 ; S D=.40)$, (b) I work to achieve ethical excellence (integrity) in my Extension work. $(M=4.70 ; S D=.459)$, (c) I easily work independently. $(M=4.70 ; S D=.497)$, and (d) I set professional goals. $(M=4.59 ; S D=.540)$. The survey items scoring with the lower scores were (a) I balance my personal and professional life. $(M=3.27 ; S D=1.078)$, (b) I handle stress effectively. $(M=3.52 ; S D=.965)$, (c) I can easily manage my professional calendar. $(M=3.69$; $S D=.988)$, (d) I am confident in strategic program planning. ( $M=3.78 ; S D=.942)$ and I am present in the moment. $(M=3.78 ; S D=.942)$. 
Table 4

Extension Educators' Perceptions of Intrapersonal Leadership Competencies

\begin{tabular}{|c|c|c|c|}
\hline Items & $n$ & M & SD \\
\hline I have a clear set of values that I apply in the workplace & 110 & 4.80 & .400 \\
\hline I work to achieve ethical excellence (integrity) in my Extension work. & 111 & 4.70 & .459 \\
\hline I easily work independently & 111 & 4.70 & .497 \\
\hline I set professional goals & 111 & 4.59 & .540 \\
\hline I achieve my professional goals & 111 & 4.34 & 064 \\
\hline I have effective written communication skills & 111 & 4.32 & .632 \\
\hline I have effective oral communication skills & 111 & 4.31 & .600 \\
\hline I am an effective listener & 111 & 4.25 & .595 \\
\hline I apply what I know about my personal leadership style in my daily work & 111 & 4.16 & .668 \\
\hline I use a personal leadership philosophy to guide my work & 109 & 4.12 & .868 \\
\hline $\begin{array}{l}\text { I apply emotional intelligence (EQ; the ability to recognize and manage } \\
\text { the emotions of self and others) concepts within my Extension work }\end{array}$ & 108 & 4.05 & .778 \\
\hline $\begin{array}{l}\text { I apply cultural intelligence (CQ; the ability to navigate culturally diverse } \\
\text { settings) concepts within my Extension work }\end{array}$ & 108 & 4.03 & .729 \\
\hline $\begin{array}{l}\text { I easily prioritize tasks when I am involved in various } \\
\text { projects }\end{array}$ & 111 & 4.01 & .889 \\
\hline I quickly make decisions & 111 & 3.79 & .926 \\
\hline I am confident in strategic program planning & 110 & 3.78 & .942 \\
\hline I am present in the moment & 110 & 3.78 & .942 \\
\hline I can easily manage my professional calendar & 111 & 3.69 & .988 \\
\hline I handle stress effectively & 110 & 3.52 & .965 \\
\hline I balance my personal and professional life & 111 & 3.27 & 1.078 \\
\hline Overall intrapersonal leadership skills & 111 & 4.12 & .378 \\
\hline
\end{tabular}

Note: 1 = strongly disagree, 2 = disagree, 3 = neither disagree or agree, 4 = agree, $5=$ strongly agree

The second research objective was to describe Extension educators' perceptions of their interpersonal leadership competencies. The mean summative score for the interpersonal leadership scale was 4.04 (SD =.467, $n=111)$. Results for this objective are shown in Table 5. Lower scores indicate greater needs of intrapersonal leadership skills content areas, and higher scores indicate greater proficiency in the area. The survey items scoring the highest mean values were (a) I work to establish trust with the people I work with. $(M=4.55 ; S D=.568)$, (b) I easily collaborate with others on projects. $(M=4.38 ; S D$
$=.574)$, (c) I form internal partnerships (i.e. with other Extension professionals) to enhance my work. ( $M=$ 4.38; $S D=.639$ ), and (d) I form external partnerships in the community to enhance my work. $(M=4.35$; $S D$ $=.715)$. The survey items scoring the lowest mean values were (a) I lead organizational change within my role. $(M=3.60 ; S D=1.078)$, (b) I delegate tasks effectively ( $M=3.64 ; S D=.842)$, and (c) I effectively engage in difficult conversations (i.e. negotiation with external stakeholders, ethical situations involving volunteers, etc.). $(M=3.68 ; S D=.838)$. 
Table 5

Extension Educators' Perceptions of Interpersonal Leadership Competencies

Items

n
M

SD

\begin{tabular}{|c|c|c|c|}
\hline I work to establish trust with the people I work with & 110 & 4.55 & .568 \\
\hline I easily collaborate with others on projects & 110 & 4.38 & .574 \\
\hline $\begin{array}{l}\text { I form internal partnerships (i.e. with other Extension professionals) } \\
\text { to enhance my work }\end{array}$ & 107 & 4.38 & .639 \\
\hline I form external partnerships in the community to enhance my work & 108 & 4.35 & .715 \\
\hline I am comfortable working with diverse audiences & 110 & 4.30 & .671 \\
\hline I am comfortable working in group settings & 110 & 4.26 & .700 \\
\hline I am comfortable networking with other colleagues & 110 & 4.25 & .900 \\
\hline I run efficient meetings & 108 & 4.24 & .639 \\
\hline I am efficient at connecting people to organizational resources & 109 & 4.18 & .735 \\
\hline I solve complex problems & 109 & 4.13 & .668 \\
\hline $\begin{array}{l}\text { I build coalitions (i.e., with local government and local non-profit } \\
\text { agencies) to achieve community goals }\end{array}$ & 100 & 3.96 & .887 \\
\hline I work to engage in shared leadership within my Extension work & 107 & 3.96 & .726 \\
\hline I am good at managing people & 100 & 3.91 & .753 \\
\hline I am effective at motivating others & 108 & 3.89 & .728 \\
\hline I facilitate community discussion groups easily & 95 & 3.88 & .823 \\
\hline I am good at negotiating & 109 & 3.83 & .866 \\
\hline I am good at navigating conflict & 109 & 3.73 & .919 \\
\hline I am good at coaching early career Extension professionals & 97 & 3.73 & .919 \\
\hline $\begin{array}{l}\text { I effectively engage in difficult conversations (i.e. negotiation with } \\
\text { external stakeholders, ethical situations involving volunteers, etc.) }\end{array}$ & 105 & 3.68 & .838 \\
\hline I delegate tasks effectively & 106 & 3.64 & .842 \\
\hline I lead organizational change within my role & 101 & 3.60 & 1.078 \\
\hline Overall interpersonal leadership skills & 110 & 4.04 & .467 \\
\hline
\end{tabular}

Note: 1 = strongly disagree, 2 = disagree, 3 = neither disagree or agree, 4 = agree, 5 = strongly agree

The third research objective was to describe Extension educators' perceptions of their support for change. The mean summative score for support for change was $4.00(S D=.616, n=107)$. Results for this objective are shown in Table 6. 
Table 6

Support for Organizational Change

\begin{tabular}{llll}
\hline Item & $\mathbf{n}$ & $\mathbf{M}$ & SD \\
\hline I certainly comply with organizational change & 107 & 4.04 & .643 \\
\hline I agree with organizational change & 107 & 4.00 & .740 \\
\hline I can accept organizational change & 107 & 3.98 & .752 \\
\hline Overall support for organization change & 107 & 4.00 & .616 \\
\hline
\end{tabular}

Note: 1 = strongly disagree, 2 = disagree, 3 = neither disagree nor agree, 4 = agree, 5 = strongly agree

The fourth research objective was to explain the relationship between Extension educators' perceptions of support for change and intrapersonal and interpersonal leadership competencies. Application of the Pearson correlation coefficient showed a positive, very strong association between interpersonal and intrapersonal leadership 7

\section{Table 7}

Interrelationship Among Overall Support for Organizational Change and Leadership Competencies Domains

\begin{tabular}{|l|l|l|l|}
\hline Items & $\begin{array}{l}\text { Intrapersonal } \\
\text { leadership }\end{array}$ & $\begin{array}{l}\text { Interpersonal } \\
\text { leadership }\end{array}$ & $\begin{array}{l}\text { Support for } \\
\text { organizational } \\
\text { change }\end{array}$ \\
\hline Intrapersonal leadership & 1 & & \\
\hline Interpersonal leadership & $777^{\star \star}$ & 1 & 1 \\
\hline $\begin{array}{l}\text { Support for organizational } \\
\text { change }\end{array}$ & $.238^{\star}$ & $.389^{* \star}$ & 1 \\
\hline
\end{tabular}

Note: ${ }^{\star} p<.05 ;{ }^{*} p<.01$

A multiple linear regression analysis was conducted to determine the relationship between overall support for organizational change (dependent variable) and independent variables such as intrapersonal leadership skills and intrapersonal leadership skills. The results indicated that a significant proportion of the total variation in overall support for change was predicted by intrapersonal leadership competencies and interpersonal leadership competencies, $F(2$, $104)=10.024, p<.001$. Multiple $R^{2}$ indicated that approximately $16.2 \%$ of the variation in support for change can be explained by Extension educators' competencies ( $r=.777, p=.001$ ); a positive moderate association was found between support for change and interpersonal leadership competencies $(r=.389$, $p=.001)$; and a slightly positive association was found between support for change and intrapersonal leadership competencies ( $r=.238, p=.013$ ), see Table 7. 


\section{Table 8}

Multiple Regression Analysis Between Support for Organizational Change and Leadership Competencies Domains

\begin{tabular}{|c|c|c|c|c|c|c|c|c|c|}
\hline \multicolumn{10}{|c|}{ Model Fit } \\
\hline & & \multicolumn{8}{|c|}{ Change Statistics } \\
\hline & $R$ & $R^{2}$ & Adj. $R$ & $S E$ & $R^{2}$ & $F$ & $d f 1$ & $d f 2$ & $p$ \\
\hline $1^{a}$ & $.402^{a}$ & .162 & .145 & .56940 & .162 & 10.024 & 2 & 104 & .000 \\
\hline
\end{tabular}

a. Predictors: intrapersonal leadership competencies and interpersonal leadership competencies.

b. $\quad$ Dependent variable: support for organizational change

\section{Table 9}

Analysis of Variance in Support for Organizational Change

\begin{tabular}{cccccc}
\hline Model & $\begin{array}{c}\text { Sum of } \\
\text { Squared }\end{array}$ & $d f$ & Mean Square & $F$ & $p$ \\
\hline Regression & 6.500 & 2 & 3.250 & 10.024 & $.000^{\mathrm{b}}$ \\
\hline Residual & 33.718 & 104 & .324 & & \\
\hline Total & 40.218 & 106 & & & \\
\hline
\end{tabular}

a. Dependent variable: support for organizational change

b. Predictors: intrapersonal leadership competencies and interpersonal leadership competencies.

\section{Table 10}

Multiple Relations Coefficients

\begin{tabular}{lcccc}
\hline \multicolumn{1}{c}{ Model } & $B$ & SER & $\beta$ & $p$-value \\
\hline Constant & 2.336 & .600 & & .000 \\
\hline Intrapersonal leadership & -.259 & .229 & .262 & 2.62 \\
\hline Interpersonal leadership & .675 & .187 & .514 & .001 \\
\hline
\end{tabular}

Within the final model, one of the predictors was statistically significant. The strongest predictor of support for change was interpersonal leadership competencies $(\boldsymbol{\beta}=.514 ; p$-value $<.001)$. Intrapersonal leadership skills $(\boldsymbol{\beta}=.262 ; p$-value $=2.62$ ) was a statistically insignificant predictor of support for change. 


\section{Figure 1}

Residual Plot

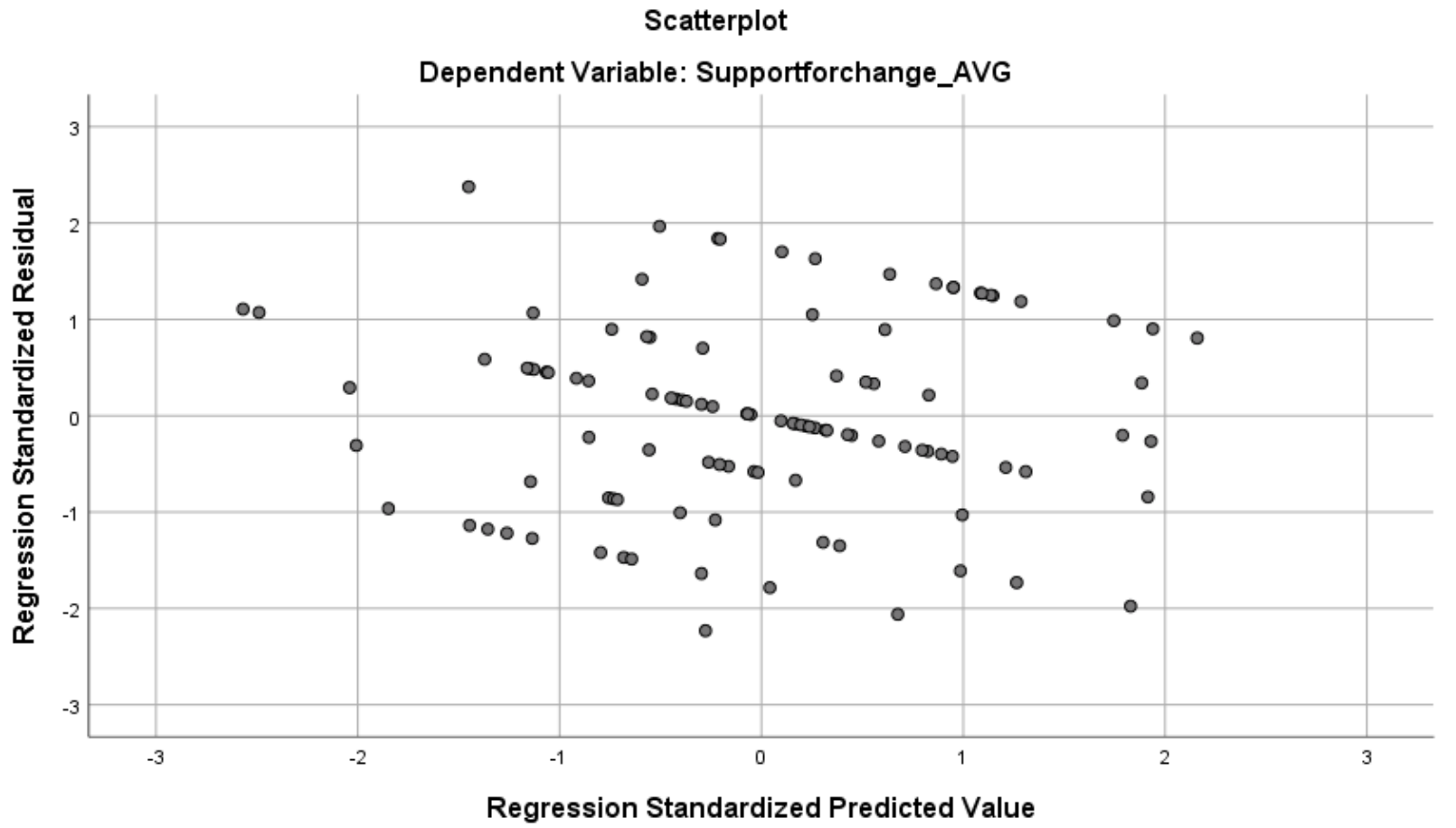

\section{Discussion}

Knowledge of leadership competencies of Extension professionals is needed for the modern Extension organization (Hyde, J, \& Cason, K., personal communication, October 2018). In concert, it is important to understand how receptive Extension professionals may be to organizational change as Extension engages in organizational restructuring. Our results indicate that Penn State Extension professionals have high levels of intrapersonal leadership in the areas of values, ethics, and workplace independence. These findings align with Hayne's (2000) findings, which indicated decisionmaking, assertiveness, and willingness to take initiative are important leadership competencies for Extension educators. Extension professionals had lower scores in the following areas: work life balance, stress management, strategic program planning, and mindfulness. Findings for work life balance, mindfulness, and stress management align with Kroth and Peutz's (2011) study, which found that
Extension professionals ranked work life balance and burnout as highly important issues. Findings related to strategic program planning also align with the literature, as this was recently identified as an important area of professional development for Extension educators (Baker \& Hadley, 2014).

Extension professionals scored high for levels of interpersonal leadership under the topics trust, collaboration, and partnerships. The importance of these interpersonal skills abilities aligns with Hayne's (2000) and Benge and Sowcik's (2018) findings related to the importance of collaboration and the ability to build strong relationships with others for Extension professionals. Lower scores were reported for leading change, delegation, and difficult discussions, and the importance of these competencies aligns with the literature. Byrne (2017) identified time management and delegation as key competencies needed for $4-\mathrm{H}$ professionals, yet Harder and Narine (2020) found that Extension professionals, on average, score low in ability for these areas. Harder's (2009) commentary 
also aligned with our findings, noting that there is a need to support educators as they lead change. Fry and Langetto (2014) found that Extension educators receive little to no conflict management training, supporting our findings related to the need for support for Extension educators when navigating difficult conversations.

We found that on average, Extension professionals mostly support change. These findings align with Bloir and Scheer's (2017) findings. In concert, we found that there is a positive significant correlation between support for change and Extension educators' intrapersonal and intrapersonal leadership competencies. Intrapersonal and interpersonal leadership competencies predicted a significant proportion of the total variation in overall support for change $(16.2 \%), F(2,104)=10.024, p<.001$. These findings align with Struckmeyer et al.'s (2019) work, which found that leadership competence may indicate Extension educators' receptivity to change.

\section{Implications}

Our study has implications for the future study of Extension leadership and support for organizational change, as well as implications for Extension leadership professional development practitioners, and aligns with previous literature. As mentioned earlier, our study indicated a lack of literature related to support for change studies among Extension professionals, and existing studies contradicted some of our findings. Only one study was identified that examined the relationship between intrapersonal and interpersonal leadership competencies and support for change among Extension educators (Struckmeyer, 2019). Struckmeyer found that leadership efficacy informs receptivity to organizational change. Leadership development training can increase leadership efficacy (Propst \& Koesler, 1998) and therefore may increase receptivity to organizational change for Extension educators. More studies across other statewide Extension systems should be conducted in these areas, as there is a need for a more rigorous scientific base in the areas of leadership competence and support for change in Extension, as Extension is in the process of working to restructure to address the needs of modern society and there is a lack of substantial literature in this area.

Extension leaders and leadership development practitioners should consider preparing Extension personnel be more receptive and adaptable to organizational change. Kinsey (2010) mentioned that "specific leadership approach at all levels of an organization can adopt in order to address and deal with change", p.1. The authors emphasized that Extension leaders should taking specific actions in order to solve issues within organizations that help organization employees "move patiently, carefully, and incrementally" through organization change (Badaracco, 2002). Leadership development practitioners and Extension faculty members developing leadership professional development materials for Extension professionals should focus on topics we identified as lower scoring, namely work life balance, stress management, strategic program planning, mindfulness, leading change, delegation, and difficult discussions/conflict management. Our results indicate new educational materials may be needed for these areas, or existing materials may need revision. Based on the results of this study, we recommend adding an annual required training each year based on leadership development needs assessment results to improve leadership education efforts. Leadership assessments should continue to be conducted annually to help address the changing needs in an educators' professional work environment that help support and engage in organizational change. We also recommend that educators be required to attend at least two webinars related to the interpersonal leadership competence development as a result of our assessments. Finally, we recommend that Extension leadership be provided with consistent training related to change management to effectively guide Extension educators through change, as none had been completed prior to this assessment. However, each state system 
should exercise caution when applying these results to guide future professional development curriculum and training development, as competencies needed for Extension professionals have varied by state in past studies (Culp et al., 2007).

Extension organizations must successfully navigate organizational change, while simultaneously helping personnel develop the capacity to thrive as ongoing and future challenges and opportunities arise (Frahm \& Brown, 2002; Smith \& Torppa, 2010). Previous research indicated that a primary task of organizational leaders and leadership education is to manage and guide change (Graetz, 2000; Smith \& Torppa, 2010; Stace \& Dunphy, 1996;). Leadership education is fundamental in advancing Extension educators' intrapersonal and interpersonal leadership competencies. A leadership education program can help to prepare Extension educators to support organizational change. We encourage each state Extension system to follow our method, but ensure that the instrument is reviewed by a panel in their state, piloted among a group of Extension professionals in their state, and then distributed among Extension professionals across their state to ensure geographic relevance of results. Using a census approach like ours will also ensure more representative results. Repetition of our process across other state Extension systems should help to better understand intrapersonal and interpersonal leadership competencies needs among today's Extension professionals, how these individuals are viewing organizational change, and the relationship between Extension educators' leadership competence and support for change.

In conclusion, support for organizational change can be initiated through leadership development programs that use of action learning sets to improve leaders' leadership competencies (McRoy $\&$ Gibbs, 2009). The funding from this study showed significant relationship between support for organizational change and educators' interpersonal competencies. Extension administrators and leadership development practitioners should take into consideration that Extension educators not only require intrapersonal leadership competencies and the knowledge needed in their role, but also in those competencies that require unique interpersonal leadership skills in Extension settings based on organizational history, culture, and trends. These include an understanding of how to establish trust with the new community, collaborate with others, form internal and external partnerships, work with diverse audience, navigate conflict, engage in difficult conversation, motivate, and manage others. Also, it is important understand the impact those interpersonal leadership competencies can have on the change process, the barriers to change in Extension settings, an understanding of assessment, the leadership research on organizational change, professional development, and the process and the criteria that can be used for rewarding employees. Moreover, it is quite common for leadership development programs to focus on the enhancement of interpersonal skills, there has been little systematic research focusing specifically on the effectiveness of such training efforts. 


\section{References}

Argabright, K.J., Davis, G. A., Torppa, C.B., King, J., Scheer, S.D., Stollar., M.K. (2019). Developing and Supporting the Future Extension Professional. Journal of Extension, 57(4). https://www.joe.org/ joe/2019august/comm1.php

Avolio, B. J., \& Gardner, W. L. (2005). Authentic leadership development: Getting to the root of positive forms of leadership. The Leadership Quarterly, 16(3), 315-338. https://doi.org/10.1016/j.leaqua.2005.03.001

Badaracco, J. L., Jr. (2002). Leading quietly: An unorthodox guide to doing the right thing. Boston: Harvard Business School Press.

Baker, L. M., \& Hadley, G. (2014). The New Agent: A Qualitative Study to Strategically Adapt New Agent Professional Development. Journal of Extension, 52(5). https://www.joe.org/joe/2014october/a3.php

Bass, B. M. (1985). Leadership and performance beyond expectations. Free Press.

Bass, B. M. (1996). New paradigm of leadership: An inquiry into transformational leadership. US Army Research Institute for the Behavioral and Social Sciences.

Bass, B. M. (1999). Two decades of research and development in transformational leadership. European Journal of Work and Organizational Psychology, 8(1). https://doi.org/10.1080/135943299398410

Bass, B. M. (1990). Bass \& Stogdill's handbook of leadership, 3rd ed. Free Press.

Battilana, J., Gilmartin, M., Sengul, M., Pache, A. C., \& Alexander, J. A. (2010). Leadership competencies for implementing planned organizational change. The Leadership Quarterly, 21(3). https://www.sciencedirect. com/science/article/pii/S104898431000055X

Beer, M., \& Nohria, N. (Eds.). (2000). Breaking the code of change. Harvard Business Review. 78(3). Harvard business school press.

Benge, M., Harder, A., \& Carter, H. (2011). Necessary pre-entry competencies as perceived by Florida Extension agents. Journal of Extension, 49(5). https://www.joe.org/joe/2011october/a2.php

Benge, M., \& Sowcik, M. (2018). Online Leadership Short Course for County Extension Directors. Journal of Extension, 56(6), https://eric.ed.gov/?id=EJ1194932

Bloir, K., \& Scheer, S. D. (2017). Exploring Employee Readiness for Change in a State Extension System. Journal of Extension, 55(6). https://www.joe.org/joe/2017december/pdf/JOE_v55_6a3.pdf

Bolman, L. G., \& Deal, T. E. (2017). Reframing organizations: Artistry, choice, and leadership. John Wiley \& Sons.

Boyd, B. L. (2004). Extension agents as administrators of volunteers: Competencies needed for the future. Journal of Extension, 42(2), 23-31. https://www.joe.org/joe/2004april/a4.php

Bouty, I. (2000). Interpersonal and interaction influences on informal resource exchanges between R\&D researchers across organizational boundaries. Academy of Management Journal, 43(1). https://doi. org/10.5465/1556385 
Bourdieu, P. (1986). The forms of capital. Greenwood.

Boyce, L. A., Zaccaro, S. J., \& Wisecarver, M. Z. (2010). Propensity for self-development of leadership attributes: Understanding, predicting, and supporting performance of leader self-development. The Leadership Quarterly, 21(1), 159-178. https://doi.org/10.1016/j.leaqua.2009.10.012

Bruce, J. A., \& Anderson, J. (2012). Perceptions of the training needs of the newest members of the Extension family. Journal of Extension, 50(6). https://www.joe.org/joe/2012december/pdf/JOE_v50_6rb5.pdf

Byrne, C. (2017). Growing together: 4-H professional, research, knowledge and competencies 2017. https://nifa. usda.gov/sites/default/files/resources/4-H\%20PRKC\%202017\%20Guide.pdf

Coleman, J. S. (1988). Social capital in the creation of human capital. American Journal of Sociology, 94, S95-S120. https://www.journals.uchicago.edu/doi/abs/10.1086/228943

Conklin, N. L., Hook, L. L., Kelbaugh, B. J., \& Nieto, R. D. (2002). Examining a professional development system: A comprehensive needs assessment approach. Journal of Extension, 40(5). https://www.joe.org/ joe/2002october/a1.php

Clampitt, P. G., \& Williams, M. L. (2005). Conceptualizing and measuring how employees and organizations manage uncertainty. Communication Research Reports, 22(4), 315-324. https://doi. org/10.1080/00036810500317649

Cooper, A. W., \& Graham, D. L. (2001). Competencies needed to be successful county agents and county supervisors. Journal of Extension, 39(1). https://www.joe.org/joe/2001 february/rb3.php

Culp, K., McKee, R.K. \& Nestor, P. (2007). Identifying volunteer core competencies: regional differences. Journal of Extension, 45(6). https://www.joe.org/joe/2007december/a3.php

Davis. J.A. (1971). Elementary survey analysis. Prentice-Hall.

Day, D. V. (2000). Leadership development: A review in context. The Leadership Quarterly, 11(4). https://doi. org/10.1016/S1048-9843(00)00061-8

Day, D. V., \& Dragoni, L. (2015). Leadership development: An outcome-oriented review based on time and levels of analyses. Annual Review of Organizational Psychology and Organizational, 2(1). https://doi. org/10.1146/annurev-orgpsych-032414-111328

Dillman, D. A., Smyth, J. D., \& Christian, L. M. (2014). Internet, phone, mail, and mixed-mode surveys: the tailored design method. John Wiley \& Sons.

Fleishman, E. (1953). Leadership climate, human relations training, and supervisory behavior. Personnel Psychology, 6, 205-222.

Franz, N. K., Peterson, R. S., \& Dailey, A. L. (2002). Leading organizational change: a comparison of county and campus views of extension engagement. Journal of Extension, 40(3), 23-32. https://www.joe.org/ joe/2002june/rb1.php

Fry, J. B., \& Langellotto, G. A. (2013). Generating potential solutions for dealing with problem volunteers. Journal of Extension, 51(6). https://www.joe.org/joe/2013december/tt3.php 
Galli, E. B., \& Müller-Stewens, G. (2012). How to build social capital with leadership development: Lessons from an explorative case study of a multibusiness firm. The Leadership Quarterly, 23(1), https://doi. org/10.1016/j.leaqua.2011.11.014

Gardner, J. (1993). On leadership. Simon and Schuster.

Goleman, D. (2003). What makes a leader. In Organizational influence processes, Eds.: Porter, L. W., Angele, H. L., Allen, R.W. Sharpe. Inc.

Graetz, F. (2000). Strategic change leadership. Management Decision, 38 (8) https://doi. org/10.1108/00251740010378282

Harder, A., \& Narine, L. K. (2020). Personal health, role, and time management competency training needs of Florida extension agents. Journal of Extension, 58(1). https://joe.org/joe/2020february/a4.php

Harder, A. (2019). Public value and partnerships: Critical components of extension's future. Journal of Extension, 57(3). https://www.joe.org/joe/2019june/pdf/JOE_v57_3comm1.pdf

Haynes, B. R. (2000). Management skills of county Extension administrators: Are they sufficient to do the job? Journal of Extension, 38(2). https://www.joe.org/joe/2000april/rb2.php

Helms Mills, J., Dye, K. and Mills, A.J. (2009), Understanding Organizational Change, Routledge, London.

House, R. J., \& Aditya, R. N. (1997). The social scientific study of leadership: Quo vadis? Journal of management, 23(3), 409-473. https://doi.org/10.1016/S0149-2063(97)90037-4

Kaufman, E., Mitra, S., Anderson, J., Coartney, J., \& Cash, C. (2020). Leading Collaborative Change in an Educational Organization. Leadership Education 19(4). https://doi.org/10.12806/V19//4/R5

Kinsey, S. B. (2010). Quiet leadership: How to create positive change without the noise and negativity. Journal of Extension, 48(5), 1-4. https://www.joe.org/joe/2010october/tt2.php

Kroth, M., \& Peutz, J. (2011). Workplace issues in Extension-A delphi study of Extension educators. Journal of Extension, 49(1). https://www.joe.org/joe/2011 february/rb1.php

Lakai, D., Jayaratne, K. S. U., Moore, G. E., \& Kistler, M. J. (2014). Identification of current proficiency level of Extension competencies and the competencies needed for Extension agents to be successful in the 21st century. Journal of Human Sciences and Extension, 2(1). https://www.jhseonline.com/article/view/584

Ladewig, H., \& Rohs, F. R. (2000). Southern Extension leadership development: Leadership development for a learning organization. Journal of Extension, 38(3). https://www.joe.org/joe/2000june/a2.php

Likert, R. (1961). New patterns of management. McGraw-Hill

Limerick, D., \& Cunnington, B. (1993). Managing the new organization: A blueprint for networks and strategic alliances. Media Info

Lindner, J. R., Murphy, T. H., \& Briers, G. E. (2001). Handling nonresponse in social science research. Journal of Agricultural Education, 42(4), 43-53. https://www.jae-online.org/attachments/article/387/42-04-43.pdf

Miller, L. E., \& Smith, K. L. (1983). Handling nonresponse issues. Journal of Extension, 21(5). http://www.joe.org/ 
joe/1983september/83-5-a7.pdf.

McCauley, C. D. (2000). A systemic approach to leadership development. Paper presented at the 15th Annual Conference of the Society for Industrial and Organizational Psychology, New Orleans, LA, United States.

McRoy, I., \& Gibbs, P. (2009). Leading change in higher education. Educational Management Administration \& Leadership, 37(5), 687-704. https://doi/pdf/10.1177/1741143209339655

Meeting Professionals International (MPI). (2012). Meeting and business event competency standards curriculum guide. https://www.mpi.org/docs/default-source/Research-and-Reports/MBECS-Guide-AIntroduction.pdf

Mumford, T. V., Campion, M. A., \& Morgeson, F. P. (2007). The leadership skills strataplex: Leadership skill requirements across organizational levels. The Leadership Quarterly, 18(2), 154-166. https://doi. org/10.1016/j.leaqua.2007.01.005

Murray, P., \& Blackman, D. (2006). Managing innovation through social architecture, learning, and competencies: a new conceptual approach. Knowledge and Process Management, 13(3), 132-143. https:// onlinelibrary.wiley.com/doi/epdf/10.1002/kpm.253

Nikolaou, I., Gouras, A., Vakola, M., \& Bourantas, D. (2007). Selecting change agents: Exploring traits and skills in a simulated environment. Journal of Change Management, 7(3-4), 291-313. https://www. tandfonline.com/doi/abs/10.1080/14697010701779173

Paxson, M., Howell, R. E., Michael, J. A., \& Wong, S. K. (1993). Leadership development in Extension. Journal of Extension, 31(1). https://www.joe.org/joe/1993spring/rb2.php

Pettigrew, A., Ferlie, E., \& McKee, L. (1992). Shaping Strategic Change: Making change in large organizations, the case of the NHS. Sage Publications.

Propst, D. B., \& Koesler, R. A. (1998). Bandura goes outdoors: Role of self-efficacy in the outdoor leadership development process. Leisure Sciences, 20(4), 319-344. https://doi.org/10.1080/01490409809512289

Radhakrishna, R. B. (2001). Professional development needs of state extension specialists. Journal of Extension, 39(5). https://www.joe.org/joe/2001october/rb4.php

Ricketts, K. G., Carter, H. S., Place, N. T., \& McCoy, T. (2012). A look inside: Self-leadership perceptions of extension educators. Journal of Extension, 50(5). https://www.joe.org/joe/2012october/pdf/JOE_v50_5a3. pdf

Riggio, R. E., \& Lee, J. (2007). Emotional and interpersonal competencies and leader development. Human Resource Management Review, 17(4), 418-426. https://doi.org/10.1016/j.hrmr.2007.08.008

Scheer, S. D., Ferrari, T. M., Earnest, G. W., \& Connors, J. J. (2006). Preparing extension professionals: The Ohio State University's model of extension education. Journal of Extension, 44(4), 1-12. https://www.joe. org/joe/2006august/a1.php

Smith, K. L., \& Torppa, C. B. (2010). Creating the capacity for organizational change: Personnel participation and receptivity to change. Journal of Extension, 48(4). https://joe.org/joe/2010august/a1.php

Struckmeyer, K. M., Peek, G., Tripp, P. J., Bishop, A. J., \& Gordon, S. R. (2019). Family and consumer sciences extension agent receptiveness to innovative caregiving programming. Journal of Extension, 57(6). https:// www.joe.org/joe/2019december/rb6.php 
Stebbings, H., \& Braganza, A. (2009). Exploring continuous organizational transformation: Morphing through network interdependence. Journal of Change Management, 9(1). https://www.tandfonline.com/doi/ abs/10.1080/14697010902727161

Stedman, N. L., \& Rudd, R. (2006). Leadership styles and volunteer administration competence: Perceptions of 4-H county faculty in the United States. Journal of Extension, 44(1). https://www.joe.org/ joe/2006february/rb6.php

Subramony, M., Segers, J., Chadwick, C., \& Shyamsunder, A. (2018). Leadership development practice bundles and organizational performance: The mediating role of human capital and social capital. Journal of Business Research, 83, 120-129. https://doi.org/10.1016/j.jbusres.2017.09.044

Tondl, R. M. (1991). Climate for change in Extension. Journal of Extension, 29(3). https://www.joe.org/ joe/1991 fall/a4.php

Tsai, W., \& Ghoshal, S. (1998). Social capital and value creation: The role of intrafirm networks. Academy of management Journal, 41(4), 464-476. https://doi.org/10.5465/257085

Uhl-Bien, M. (2003). Relationship development as a key ingredient for leadership development. In S. E. Murphy \& R. E. Riggio (Eds.), The future of leadership development (pp. 129-147). Lawrence Erlbaum Associates.

Ulvenblad, P., Hoveskog, M., Tell, J., Ulvenblad, P. O., Ståhl, J., \& Barth, H. (2014). Agricultural business model innovation in Swedish food production: the influence of self-leadership and lean innovation. In DRUID Society Conference 2014 on Entrepreneurship-Organization-Innovation, Copenhagen Business School (CBS), Copenhagen, Denmark._http://www.diva-portal.org/smash/get/diva2:746588/FULLTEXT01.pdf

United State Department of Agriculture, 4-H Youth Development. (2017). Growing Together: 4-H professional, research, knowledge and competencies. https://nifa.usda.gov/sites/default/files/resources/4-H\%20PRKC\%20 2017\%20Guide.pdf

Vithessonthi, C., \& Schwaninger, M. (2008). Job motivation and self-confidence for learning and development as predictors of support for change. Journal of Organizational Transformation \& Social Change, 5(2). https:// doi.org/10.1386/jots.5.2.141_1

Weiner, B. J. (2020). A theory of organizational readiness for change. In Handbook on Implementation Science. Edward Elgar Publishing.

Woodrum, W., \& Safrit, D. (2003). Leadership practices of West Virginia University extension agents working with the 4-H youth development program. Journal of Extension, 41(3). http://www.joe.org/joe/2003june/ rb3.html.

Yukl, G. (1999). An evaluation of conceptual weaknesses in transformational and charismatic leadership theories. The Leadership Quarterly, 10(2), 285-305. https://doi.org/10.1016/S1048-9843(99)00013-2

Yukl, G. (2009). Leading organizational learning: Reflections on theory and research. The Leadership Quarterly, 20(1), 49-53. https://doi.org/10.1016/j.leaqua.2008.11.006

Zaccaro, S. J., \& Banks, D. (2004). Leader visioning and adaptability: Bridging the gap between research and practice on developing the ability to manage change. Human Resource Management. 43(4), 367-380. https://onlinelibrary.wiley.com/doi/epdf/10.1002/hrm.20030 